\title{
EFFECTS OF ENVIRONMENT CONDITION ON THE POPULATION OF BRONTISPA LONGISSIMA GESTRO AND ITS PREDATOR CHELISOCHES SPP. IN NORTH LAMPUNG
}

by

\author{
Willy A. Baringbing ${ }^{1}$ and Bariyah-Baringbing ${ }^{2}$
}

\begin{abstract}
A field study to investigate the effects of environment conditions on the population density of the coconut hispid Brontispa longissima Gestro and its predotor Forficulid Chelisoches spp. was carried out in Sin ar Saerang mandiri (SSM) coconut plantation and its surrounding area, North Lampung, in May 1993. 120 trees taken at random with 1,200 still folded leaflets in 4 locations, 300 palms each, in the SW garden were observed. Another 120 trees, also taken at random, in similar patterns as that of the S.W were studied. Chemical treatments were conducted regularly in the XSM area but none in the surrounding area.
\end{abstract}

Results of the study showed that B. Longissma and its predator Chelisoches populations were found to be higher in the S.W.' garden than that of the surrounding coconut plantation. Those species of Chelisoches outside the garden and only one inside the area.

\section{INTRODUCTION}

The coconut palm, Cocos nucifiera Linnaeus, is one of the major industrial crops in Lampung province. Based on total area of 181,193 ha, about $96 \%$ are operated by small holders and only 8,328 ha or $5.14 \%$ are owned by big companies (Ditjenbun, 1989).

One of the factors causing the clecrease of nut production in the province is pest infestation such as, Hidari irava Moore, Brontispa longissima Gestro, Artona catoxantha Hanipson, Oryctes rhinoceros Linnaeus, Rhynchophorus ferrugineus OlIvIere, and various species of grasshoppers. This paper discusses the effects of the environment conditions on the population density of the coconut hispid B. Longissima and its predator.

\section{Biology of Brontispa longissima Gestro}

The coconut pest, Brontispa longissima Gestro (Coleoptera: Hispidae), is one of the serious pests in the country (Tjoa, 1953, Lever, 1969, Kalshoven, 198 1). Based on total growing area attacked the hispid occupied 48 in the country (Baringbing, 1986).

The adults and the larvae feed on both surfaces of the closely oppressed leaflets, and both stages gnaw long incisions in the tissues, parallel to one another and to the veins of leaflets. When the insects are numerous, the incisions are so close to one another that the whole of the attacked part of the leaflet dies, all die leaflets are similarly injured, and photosynthesis is reduced almost to zero. Young palms less than about 8 years old suffer most, (Lever, 1969).

Adult females lay their eggs in the still-folded leaflets of both young and mature coconut palms. The eggs are brown and flat, and are laid in short chains up to 4, and sometimes singly, on the unexpanded leaflets in the bud. They hatch in 3-4 days. The whitish larva has a pair of

\footnotetext{
${ }^{1}$ Coconut Research Sub Institute, Pakuwon, West Java

${ }^{2}$ Research Institute for species and Medicinal Crops, Bogor
} 
prominent coliper-like hooks at the hind end. It becomes fully fed in about 54 weeks. The pupa moves freely, by wriggling, between the apposed surfaces of the developing leaflets and die adult emerges from it in 46 days. The whole cycle, from egg to adult occupies about 5-7 weeks in Java and Sulawesi (Kalshoven, 1981; Lever, 1969). The female matures sexually in about 2 more weeks, and then begins egg laying and produces on average 120 eggs in the course of several weeks (Kalshoven, 198 1).

Objective of the study is to investigate the effects of environment condition on the population density of the beetle B. longissima and its predator forficulid Chelisoches spp. inside and outside the Sinar Saerang Mandiri coconut garden, North Lampung.

\section{Coconut Garden Situation}

The 900 ha Sinar Saerang Mandiri (SSM) coconut plantation, $75 \mathrm{~m}$ above sea level is located in Sidodadi Village, South Sungkai subdistrict, North Lampung regency, Lampung province. The 4 year old hybrid of PB-121 coconut palms are now beginning to produce fruits. Among the trees only cocoa is grovm as an intercrop. Control of the pests, both attacking the palms and cocoa, was regularly conducted whenever the insects are present in the leaves.

Around the garden, mature coconut palms of local tall and dwarf cultivars belonging to small holders arc grown with other crops such as banana, cassava, various kinds of vegetables, com, and several species of trees like mango, jackfruit, and clove. No chemical insecticide was used in the control of the insect pest in this area.

Observations of the coconut pest B. Longissima and its predator Chelisoches spp. population were carried out in May 1993.

\section{Observations}

Based on the area attacked by B. longissima the SSM coconut garden was divided into 4 locations. Each location consisted of around 500 trees. Thirty still-folded heart leaves, taken at random, were observed from each location. Ten leaflets, 5 from each side, taken at random were cut. $B$. longissima population and its predators, chelisoches spp., in the leaflets, were then observed. There were 120 palms with 1200 leaflets in the SSM investigated. Similar method was also conducted in 4 locations outside the garden belonging to the small holders. Thus, there were 240 trees with 2,400 leaflets studied altogether.

\section{RESULTS AND DISCUSSION}

Results of the study in both areas, Sinar Saerang Mandiri (SSM) and the surrounding gardens, are shown in Tables 1 and 2. Percentages of trees attacked by the hispid, B. longissima, inside and outside the SSM garden were almost equal, $13.33 \%$ and $15.83 \%$, respec6vely. The average dispersals of the pest predator, Chelisoches spp. in both areas were also almost equal, i.e., $3,33 \%$ and $5,83 \%$. These tables show that the average population density of the hispid inside the SSM was higher than that of the surrounding gardens: 41.50 and 29.75, respectively per 300 leaflets. Population of Chelisoches spp. per 300 leaflets inside the SSM was a little bit higher than that of the outside of the garden, yet it is not significantly different statistically. 


\begin{tabular}{|l|c|c|c|c|c|c|c|}
\hline \multicolumn{2}{|c|}{ Table 1. Observation of the coconut pest B. longissima and its predator Chelisoches moris inside the Sinar } \\
Saerang Mandiri coconut garden in North Lampung \\
\hline Location & $\begin{array}{c}\text { Number of } \\
\text { palms } \\
\text { Observed }\end{array}$ & $\begin{array}{c}\text { Number of } \\
\text { leaves per } \\
\text { palm }\end{array}$ & $\begin{array}{c}\text { Number of } \\
\text { leaflets per } \\
\text { leaf }\end{array}$ & $\begin{array}{c}\text { Percentage } \\
\text { of trees } \\
\text { Attacked }\end{array}$ & $\begin{array}{c}\text { Population } \\
\text { the pest in } \\
300 \\
\text { leaflets }\end{array}$ & $\begin{array}{c}\text { Percentage } \\
\text { of C. moris } \\
\text { dispersal }\end{array}$ & $\begin{array}{c}\text { Population } \\
\text { of } \text { C. moris } \\
\text { in } 300 \\
\text { leaflets }\end{array}$ \\
\hline Antan I-A & 30 & 22.67 & 192.13 & 10.00 & 48.0 & 3.33 & 2.0 \\
Antan I-B & 30 & 20.70 & 182.63 & 13.33 & 64.0 & 6.67 & 3.0 \\
Antan 2-A & 30 & 21.77 & 185.60 & 20.00 & 30.0 & 0.00 & 0.0 \\
Antan 2-B & 30 & 20.83 & 190.57 & 10.00 & 24.0 & 3.33 & 1.0 \\
\hline Total & 120 & 85.97 & 750.57 & 52.33 & 166.0 & 13.33 & 6.0 \\
\hline Average & 30 & 21.49 & 187.73 & 13.33 & 41.5 & 3.33 & 1.5 \\
\hline
\end{tabular}

Inside the SSM garden, only one species of Chelisoches predator was obtained in the survey, that was $C$ moris $\mathrm{F}$ The outside area, belonging to the small holders, 3 species of the forficulid existed : they were $C$ moris and 2 other Chelisoches spp., unidentified yet. Heavy insecticide treatments were always implemented in the SSM area whenever leaf-eating insects occurred in the palm and cacao trees. Consequently, 2 species of the genus were forced to transfer to safer places, the surrounding coconut gardens, where no chemical control was performed. There is a possibility that $C$ moris, the only species of Chelisoches is now left in the SSM garden, will also leave the garden in time if this natural enemy could no longer tolerate the continuous insecticide destruction.

As stated earlier, cacao was the only crop grown among the palms in the SSM garden while in the outside area various kinds of crops were planted (banana, cassava, vegetable, corn, peanut, mango, jackfruit and clove). According to the natural biological control theory, pest population is lower in the area which consists of many species of plants compared to that area with only one or two crops. This theory is fully proved in the population of the hispid outside the SSM garden, in which coconut palms grown together with many other species of plants, was lower than the SSM it self.

Table 2. Observation of the coconut pest $b$. longissima and its predator Chelisoches inside the Sinar Saerang Mandiri coconut garden in North Lampung

\begin{tabular}{|c|c|c|c|c|c|c|c|}
\hline Location & $\begin{array}{l}\text { Number of } \\
\text { palms } \\
\text { Observed }\end{array}$ & $\begin{array}{c}\text { Number of } \\
\text { leaves per } \\
\text { palm }\end{array}$ & $\begin{array}{l}\text { Number of } \\
\text { leaflets per } \\
\text { leaf }\end{array}$ & $\begin{array}{c}\text { Percentage } \\
\text { of trees } \\
\text { Attacked }\end{array}$ & $\begin{array}{c}\text { Population } \\
\text { the pest in } \\
300 \\
\text { leaflets }\end{array}$ & $\begin{array}{l}\text { Percentage } \\
\text { of } C \text {. moris } \\
\text { dispersal }\end{array}$ & $\begin{array}{l}\text { Population } \\
\text { of } C \text {. moris } \\
\text { in } 300 \\
\text { leaflets }\end{array}$ \\
\hline Katanegara & 30 & 15.40 & 208.87 & 26.67 & 47 & 3.33 & 2 \\
\hline Tamanjaya & 30 & 17.20 & 183.27 & 13.33 & 6 & 10.00 & 2 \\
\hline $\begin{array}{l}\text { Gedung } \\
\text { Ketapang }\end{array}$ & 30 & 21.07 & 197.40 & 20.33 & 65 & 10.00 & 3 \\
\hline $\begin{array}{l}\text { Kota } \\
\text { Agung-2 }\end{array}$ & 30 & 14.00 & 216.07 & 3.33 & 1 & 0.00 & 0 \\
\hline Total & 120 & 67.67 & 802.61 & 63.33 & 119 & 23.33 & 7 \\
\hline Average & 30 & 16.92 & 200.65 & 15.83 & 29.75 & 5.83 & 1.75 \\
\hline
\end{tabular}

The highest population of the pest and its predator inside the SSM garden was found in Antan- 1 B block : 64 B. longissima and 3 Chelisoches, and outside the area, Gedung ketapang, had almost 65 pest and 3 predator of B. longissima inside die SSM was found in Antan-2 B block (24 insects) and 1 predator in the outside garden, Kotaagung- 2 obtained the lowest. These data show where there is higher population of the pest, higher population of the predator is also obtained where population of the pest was low, prey population was also low. It can be concluded from these data that the population of the Chelisoches is more in an area where the prey is high. 
The case for b1ological control of native pest species is technically more complicated than it is for the invading foreign pest. (Bosch et al., 1982) also mentioned that a native species must be presumed to have already associated with it ail assorment of adapted natural enemies, and after investigation, this is usually found to be die situation. This is true in the coconut gardens outside the SSM since Brontispa and Chelisoches were among the native trees in the area. To lessen the population of the pest in a long term, it is wise to introduce the pupae parasite of Tetrostichus brontispae Ferriere in areas mentioned above.

\section{CONCLUSION AND SUGGESTION}

The average population of $B$. longissima inside the SSM was higher than that of the outside garden. Manipulation of the predator Chelisoches is needed in the control of the pest. the pupae parasite of T. brontispae is suggested to be introduced in the SSM garden.

\section{ACKNOWLEDGEMENT}

The authors are grateful to Mr. J. E. Saerang, the owner of the Sinar Saerang Mandiri coconut garden, who supported the team survey in carrying out the study. Our thanks also to Mr. Surba, the SSM manager, and his staff M/S : Jefri, Toto, Hemian, Bambang, Gunawan, Silman, Lestari, Idrus, and Erwin for assistance received.

\section{REFERENCES}

Baringbing, W. A. 1996. Coconut pest in Indonesia and their control University of Hawaii, Department of Entomology, Honolulu, Hawaii 96822. 30 pp.

Bosch, R. V. D., P. S. Messenger, and A. P. Gutierrez. 1982. An introduction to biological control. Plenum press. New York and London. 247 pp.

Ditjenbun (Direktorat Jenderal Perkebunan). 1989. Statistik Perkebunan Indonesia tahun 1984-1989. Direktorat Jenderal Perkebunan, Jakarta. 51 pp.

Kalshoven, L. G. E. 198 1. Pest of crops in Indonesia. Revised and translated into English by P.A. van der Lann. PT. Ichtiar Baru-Van Houve, Jakarta, 701 pp.

Lever, R. J. A. W. 1969. Pests of Coconut palm, Food and Agriculture Organization of the United Nation, Rome 190 pp.

Tjoa, T. M. 1953. Memberantas hama-hama kelapa dan kopra. Noordhoff-Kolff, Djakarta, 270 pp. 